\title{
АНАЛІЗ ТЕОРЕТИЧНИХ ДОСЛІДЖЕНЬ 3 ПРОЕКТУВАННЯ ДИТЯЧИХ ДОШКІЛЬНИХ ЗАКЛАДІВ
}

\author{
Денис Саєнко, аспірант \\ Україна, Одеса, Одеська державна академія будівництва і архітектури
}

DOI: https://doi.org/ 10.31435/rsglobal_ws/31102018/6171

\section{ARTICLE INFO}

Received: 22 August 2018

Accepted: 26 October 2018

Published: 31 October 2018

\section{KEYWORDS}

architecture,

kindergarten,

type of kindergarten,

built-in type of kindergarten.

\begin{abstract}
The problems of designing children's preschool institutions in Ukraine are related to the need for pre-school education services to be broadly covered by children. The Government of Ukraine, and in particular the Ministry of Education, raised the issues of development and improvement of the quality of education in our country to the most urgent tasks. General education and informatization of Ukrainian society, growth of educational potential of the population, focus on increasing the amount of knowledge, starting with early childhood - all these and other provisions and directions of the development of domestic education should be reflected in the researches of Ukrainian scientists, including in the architectural and urban aspects. The consolidation of urban development, the lack of free areas for construction in prevailing urban areas, the proliferation of high-rise housing construction, the overcrowding of kindergartens puts an urgent issue in the development of new design solutions for preschool institutions built-in-type. In this sense, the priority task is the analysis of existing scientific research in the field of designing this type of preschool institutions.
\end{abstract}

Citation: Денис Саєнко. (2018) Analiz Teoretychnykh Doslidzhen z Proektuvannia Dytiachykh Doshkilnykh Zakladiv. World Science. 10(38), Vol.1. doi: 10.31435/rsglobal_ws/31102018/6171

Copyright: (C) 2018 Денис Саснко. This is an open-access article distributed under the terms of the Creative Commons Attribution License (CC BY). The use, distribution or reproduction in other forums is permitted, provided the original author(s) or licensor are credited and that the original publication in this journal is cited, in accordance with accepted academic practice. No use, distribution or reproduction is permitted which does not comply with these terms.

Вступ. Проблеми проектування дитячих дошкільних закладів в Україні пов'язані 3 потребою в масовому охопленні дітей послугами дошкільної освіти. Уряд України i, зокрема, Міністерство освіти, поставили питання розвитку і підвищення рівня якості освіти в нашій державі до найактуальніших завдань. Загальна освіченість і інформатизація українського суспільства, зростання освітнього потенціалу населення, орієнтація на збільшення обсягу знань, починаючи 3 раннього дитячого віку - всі ці та інші положення і напрями розвитку вітчизняної освіти повинні відобразитись у дослідженнях науковців України, в тому числі в архітектурно-містобудівному аспекті. Безумовно, що ринкові відносини, суттєві зміни соціальних умов, ускладнення економічних і виробничих процесів, вимагають від людини нових знань і навичок щодо вирішення технічних і інтелектуальних завдань у повсякденному житті, обумовлюючи необхідність їх безперервного розвитку і самовдосконалення починаючи 3 початкового етапу життєвого шляху.

Результати дослідження. Теоретичні дослідження становлення мережі дитячих освітніх закладів, як об'єкта архітектурно-містобудівного проектування розкриті в чисельних публікаціях. Проаналізовані вітчизняні та закордонні дисертаційні роботи, в яких частково розглядались етапи формування об'єктів освітньої галузі, роль навчальних закладів у розвитку вітчизняної архітектурно-містобудівної діяльності. Зазначені дослідження торкаються визначення особливостей формування мережі вищих навчальних закладів [1-3], архітектурно- 
типологічного розвитку загальноосвітніх закладів та архітектурно-містобудівних особливостей проектування шкіл, ліцеїв, гімназій та професійно-технічних навчальних закладів [4-15]. Для виявлення тенденцій розвитку архітектури об'єктів дошкільної системи освіти, визначення перспективних напрямків розвитку мережі навчально-виховних закладів в роботі додатково проаналізовані теоретичні роботи, присвячені розвитку освіти $[16,17]$.

На появу і розвиток дитячих дошкільних закладів в Україні вплинула соціальнополітична активність суспільства після другої світової війни, яка вимагала підвищення громадського обслуговування при забудові міських поселень. 60-ті роки ХХ століття, пов'язані 3 демократизацією громадських відносин, пошуком прогресивних форм міської забудови, розвитком масового типового будівництва, поставили перед архітектурно-містобудівними фахівцями завдання забезпечення житлових районів об'єктами соціальної сфери, в тому числі дитячими дошкільними закладами. В цей час отримала розвиток запропонована Г. О. Градовим концепція ступеневої системи обслуговування, відповідно до якої все громадське обслуговування розподілялось на ступені (рівні) залежно від частоти користування (повсякденне, періодичне та епізодичне) [18]. Максимально наближеним до споживача i первинним елементом обслуговування було визначено житлову групу, в складі якої передбачалось розміщення дитячих дошкільних закладів з повсякденним обслуговуванням. Дослідження розвитку архітектури навчально-освітніх закладів у радянський період проведено в ряді архітектурно-типологічних наукових робіт [3-8, 19-20].

Ковальська Г. Л. в чисельних наукових дослідженнях вивчала питання містобудівного розвитку мережі освітніх закладів [21-39]. Зокрема авторкою на містобудівному рівні проектування була надана пропозиція щодо впровадження у проектну діяльність вбудованоприбудованих дитячих садів, як одного з варіантів вирішення проблеми розміщення дошкільних закладів в міських районах з ущільненою забудовою. В дослідженнях Ковальської Г. Л. надані рекомендації щодо внесення змін в функціональну організацію території вбудованоприбудованих освітніх дитячих закладів, визначена площа ділянки з розрахунку на одну дитину.

Типологічні особливості проектування дитячих дошкільних закладів освіти згідно ступеневої системи обслуговування були теоретично обгрунтовані в докторських та кандидатських дисертаціях Змеула С. Г., Чехової Л. Н., Кадуріної А. О., Юрчишин О. М., Абдерезак Д., Ламехової Н. В., Кузнецової А. А., Банникової Л. П., Вавілової І. М. та ін.

У дисертаційних роботах Змеула С. Г. [40] та Чехової Л. Н. [41] велика увага приділена розміщенню будівель ДДЗ в містах і в сільській місцевості; типам обслуговування ДДЗ, які в значній мірі впливають на функціонально-планувальний склад дитячих дошкільних закладів. Авторами запропоновані пропозиції, пов'язані 3 переходом до взаємозалежної системи дошкільних закладів 3 централізованим адміністративно-господарським обслуговуванням. Такий підхід в значній мірі дозволяє вирішувати проблеми наближення ДДЗ до житла, використовувати варіанти вбудованих та прибудованих ДДЗ.

Кадуріна А. О. дослідила питання архітектурно-художніх особливостей формування структурної і середовищної організації архітектурного середовища для дошкільної освіти на прикладі дитячих закладів загально-розвиваючого, комбінованого і компенсуючого видів [42]. Авторкою сформований перцептивний образ громадського будинку для дитини; запропоновані основні типи архітектурно-художнього образу дитячого садка; виділений ряд теоретичних принципів для формування архітектурно-художнього вигляду будинку ДДЗ; розглянуто шляхи реалізації принципів за допомогою оформлення необхідними засобами виразності основних елементів дитячого садка; виявлено моменти невідповідності архітектури існуючих ДДЗ образу ДД3, добродійного для дитячого сприйняття; створено ряд рекомендацій оформлення дитячого садка з погляду перерахованих вище факторів.

Юрчишин О. М. дослідила питання проектування мережі малокомплектних груп дошкільних дитячих закладів [43]. Авторкою надані рекомендації щодо проектування ДДЗ в центральних міських районах, які мають територіальні обмеження. У своїй роботі Юрчишин О. М. обгрунтувала функціональну недоцільність будувати дитячі садки великої місткості для ущільнених центральних міських районі та запропонувала проектування компактних автономних дитячих осередків освіти (частково прибудованих до житлових будинків або інших громадських споруд), які обслуговуються централізованими фізкультурно-спортивними залами, клубними приміщеннями, закладами громадського харчування, пральними, пральні тощо.

Дослідження Юрчишин О.М. показали, що для створення дошкільного закладу надмалої місткості може бути використана функціональна схема дитячого осередку традиційної 
дошкільної установи. До його складу повинні входити наступні приміщення: групова кімната, спальня, вбиральня, кухня-буфетна, приймальна. В окремих випадках доцільно об'єднати групову та спальню в одне приміщення (за рахунок використання вмонтованих в шафи складних ліжок), що в свою чергу дає можливість зменшити площу приміщення. Садок такого типу може бути вбудованим у перший поверх будинку або прибудованим і мати окремий вхід, або ж окремо розташованим. Ці садки також класифікуються по типу житла (соціальне житло, житло економ-класу, житло бізнес-класу) і відповідно відрізняються набором приміщень. Дошкільні заклади надмалої місткості не передбачають приміщень адміністративногосподарського призначення, повинні налічувати окрему прогулянкову територію, обладнану тіньовим навісом, пісочницею та гіркою для спуску. Площа території дитячої установи повинна складати не менше як $6 \mathrm{~m}^{2}$ на одну дитину. Авторка вважає, що дитячі дошкільні заклади надмалої місткості, розташовані в центральній частині міських поселень, де неможливо організувати майданчик для прогулянки, повинні передбачати виїзд дітей за межі міста. Вказана умова передбачає організацію місця паркування для мікроавтобусу. Розрахунок мережі закладів надмалої місткості проводиться згідно існуючих норм та статистичних даних, з рекомендацією автора дослідження проектувати із розрахунку 2-3 заклади на 1000 мешканців.

Ернст Т. К. в дисертації "Принципи формування архітектурного середовища дитячих освітньо-виховних закладів" розробила теоретичні принципи, методичні рекомендації і прийоми формування архітектурного середовища дитячих освітньо-виховних закладів 3 урахуванням багатогранності психосоматичних особливостей дитини [10]. На думку авторки, на формування архітектурного середовища дитячих закладів впливають: сім зовнішніх факторів (суспільнополітичний; соціально-економічний; фактор конструктивних можливостей; природнокліматичний; ландшафтно-містобудівний; культурно-історичний; екологічний) та сім внутрішніх факторів (образно-психологічний; функціонально-організаційний; масштабно-просторовий; санітарно-фізіологічний; сенсорний; естетичний; екологічний). Основним принципом формування архітектурного середовища дитячого закладу визнано створення його цілісної архітектурної концепції на всіх рівнях організації (від зовнішнього простору через "оболонку" будівлі до іiї внутрішнього "наповнення") та на основі чотирьох головних аспектів: образного, просторово-планувального, сенсорного, екологічного. При цьому, кожен із цих аспектів може вважатись головним, а інші - підпорядкованими, але жоден з них не може бути вилученим.

Висновки. Сформована в м. Одеса мережа дитячих дошкільних закладів, як і в інших великих містах України, не відповідає сучасним вимогам демографічного, соціально-економічного та педагогічного характеру. Ретроспективний аналіз варіантів організації мережі ДДЗ на рівні житлового кварталу дозволяє робити висновок про те, що існуючі прийоми ії побудови не дозволяють враховувати можливу динаміку росту або скорочення населення, зростання темпів будівництва багатоповерхових житлових комплексів, зменшення вільного міського простору, збільшення щільності та багатоповерховості забудови. Варто окремо виділити тенденцію реконструювання та підвищення поверховості в історичному центрі крупних міст України. Проблема раціонального використання сельбищної території великих міст, а також тенденція сучасної містобудівної політики до збільшення щільності та багатоповерховості забудови диктують необхідність пошуку сучасних прийомів розміщення ДДЗ 3 об'ємно-планувальними характеристиками, які здатні гнучко реагувати на нові вимоги в процесі експлуатації. Отже тема дослідження наступного параграфу пов'язана з дослідженням досвіду проектування та будівництва дитячих дошкільних закладів в Україні, зокрема вбудовано-прибудованого типу.

\section{ЛIТЕРАТУРА}

1. Кондель-Перминова Н. Н. Роль учебных заведений в развитии архитектуры и градостроительства на Украине (конец XIX - первая треть XX века): автореф. дис. ... канд. арх.: 18.00.01 / Моск. архит. ин-т. Москва, 1989. 24 с.

2. Ольховська О.В. Формування архітектури університетських центрів XIX - першої третини XX століття (на прикладі України): автореф. дис. ... канд. арх.: 18.00.01 / Нац. акад. образотвор. мистец. і архіт. Київ, 2008. 20 с.

3. Солобай П. А. Типологические основы формирования архитектуры высших учебных заведений: дис. ... д-ра арх.: 18.00.01 / КНУСА. Киев, 2012. 280 с.

4. Ковальський Л. М. Проблеми розвитку архітектури навчально-виховних будівель: дис. ... д-ра арх.: 18.00.02 / КНУБА. Київ, 1996. 339 с. 
5. Наумов С.Ф. Проблемы архитектурной типологии зданий и комплексов профессиональнотехнического и среднего образования: дис. в форме науч. докл. ... д-ра арх.: 18.00.02 / ЦНИИЭП жилища. Москва, 1994. 61 с.

6. Саркисов С. К. Оптимизация сети школьных зданий (на примере Средней Азии): автореф. дис. ... дра арх.: 18.00.02 / ЦНИЭПЖилища. Москва, 1974. 31 с.

7. Смирнов В.В. Система и типы учебно-воспитательных зданий для школьников в структуре крупнейшего (крупного) города (исследования и рекомендации на примере Ленинграда): автореф. дис. ... д-ра арх.: 18.00.02 / Моск. арх. ин-т. Москва, 1988. 44 с.

8. Степанов В. И. Проблемы архитектуры школьных зданий: дис. ... д-ра арх.: 18.00 .02 / ЦНИИЭП учебных зданий. Москва, 1983. 376 с.

9. Дячок О. М. Принципи формування архітектури шкіл з нетрадиційними методами навчання: дис. ... канд. арх.: 18.00.02 / КНУБА. Київ, 2000. 137 с.

10. Ернст Т. К. Принципи формування архітектурного середовища дитячих освітньо-виховних закладів: автореф. дис. ... канд. арх.: 18.00.02 / НАОМА. Київ, 2007. 21 с.

11. Закрепа Л.М. Принципи архітектурної організації професійно-технічних навчальних закладів: автореф. дис. ... канд. арх.: 18.00.02 / КНУБА. Київ, 2011. 20 с.

12. Магула Т. К. Совершенствование состава помещений городских общеобразовательных школ на основе оптимизации функций пришкольных территорий (исследования и рекомендации на примере Петербурга-Ленинграда): дисс. ... канд. арх.: 18.00.02 / С-Пет. гос. арх-стр. унив. Санкт-Петербург, 2000. $132 \mathrm{c}$.

13. Начева Е. А. Совершенствование сети и типов школьных зданий в существующей застройке (на примере городов Украины): дисс. ... канд. арх.: 18.00.02 / КИСИ. Киев, 1992. 120 с.

14. Сьомка С. В. Архітектурно-планувальна організація будівель ліцеїв і гімназій (в умовах України): автореф. дис. ... канд. арх.: 18.00.02 / Київ. держ. техн. ун-т буд-ва та архітектури. Київ, 1996. 16 с.

15. Тишкевич О. П. Архітектурно-планувальна організація сільських малокомплектних шкіл: дис. ... канд. арх.: 18.00.02 / КНУБА. Київ, 2010. 192 с.

16. Медвідь Л. А. Історія національної освіти і педагогічної думки в Україні: навч. посіб. Київ: Вікар, 2003. $335 \mathrm{c}$.

17. Хижняк 3. I. Києво-Могилянська Академія в XVII-XVIII ст. Київ: Києво-Могилянська академія, 2012. $222 \mathrm{c}$.

18. Градов Г. А. Город и быт: перспективы развития системы и типов общественных зданий. Москва: Стройиздат, 1968. 252 с.

19. Слєпцов О. С. Архітектура цивільних будівель на основі відкритих збірних конструктивних систем: автореф. дис. ... д-ра арх.: 18.00.02 / КНУБА. Київ, 1999. 35 с.

20. Степанов В. И., Дворкина Е. Б., Лейбович С. Г. Новые типы зданий общеобразовательных школ. Москва: ЦНТИ, 1984. 80 с.

21. Ковальський Л. М., Ковальська Г. Л. Архітектура вищих навчальних закладів. Університети 3-го тисячоліття. Київ: Основа, 2011. 256 с.

22. Ковальська Г. Л. Архітектурне проектування навчальних закладів: навч. посіб. / Київ. нац. ун-т буд. і арх. Київ: КНУБА, 2010. 148 с.

23. Ковальський Л. М., Лях В. М., Дмитренко А. Ю., Ковальська Г. Л. Типологія громадських будинків і споруд: навч. посіб. / Київ. нац. ун-т буд. і арх. Київ: Основа, 2012. 272 с.

24. Ковальська Г. Л. Системні принципи в дослідженнях архітектурних об'єктів (на прикладі вищого навчального закладу). Перспективні напрямки проектування житлових та громадських будівель. 2003. № 5. C.109-113.

25. Ковальська Г. Л. Містобудівні умови формування нового навчального комплексу Українського державного університету економіки і фінансів. Сучасні проблеми архітектури та містобудування. 2008. № 20. С. 321-325.

26. Ковальська Г. Л. Соціально-економічні та містобудівні основи підвищення поверховості забудови навчальних закладів. Досвід та перспективи розвитку міст України. 2009. № 16. С. 178-182.

27. Ковальська Г. Л. Архітектура закладів освіти, як один із аспектів культурології містобудування. Досвід та перспективи розвитку міст Украӥни. 2013. № 24. С. 22-32.

28. Kovalska G. L. Extracurricular educational establishments formation experience in Ukraine. Вісник Придніпровської державної академії будівництва та архітектури. 2015. № 10. С. 76-81.

29. Ковальська Г. Л. Комплексне формування закладів освіти в центральних і приміських зонах. Досвід та перспективи розвитку міст Украӥни. 2010. № 18. С. 158-167.

30. Kovalskaya G. Placing of educational establishments in historical central part of city. Pressing issues and priorities in development of the scientific and technological complex. 2014. № 8. Р. 83-86.

31. Ковальська Г. Л. Формування мережі центрів художньо-естетичної творчості для дітей та юнацтва. Zbiór raportów naukowych. Najnowsze badania naukowe. Teoria, praktyka: матеріали наук.-практ. конференції (Warszawa, 30.03.2015-31.03.2015). Warszawa: Diamond trading tour, 2015. C. 11-14. 
32. Ковальська Г. Л. Розвиток системи навчальних закладів у різних містобудівних умовах. Управління розвитком складних систем. 2015. № 24. С. 118-124.

33. Ковальська Г. Л. Вплив адміністративно-територіальної реформи на формування освітніх округів на території України. Молодий вчений. 2015. № 12. С. 62-64.

34. Ковальська Г. Л. Особливості проектування та будівництва вбудовано-прибудованих дошкільних навчальних закладів. Сучасні проблеми архітектури та містобудування. 2015. № 40. С. 378-383.

35. Ковальська Г.Л. Сучасні тенденції розвитку мережі дитячих дошкільних та загальноосвітніх закладів. Досвід та перспективи розвитку міст України. 2012. № 23. С. 167-172.

36. Ковальська Г. Л. Функціонально-планувальна структура територій закладів освіти. ScienceRise. 2014. № 1(3). C.7-10.

37. Ковальська Г. Л. Властивості мережі навчально-виховних закладів як містобудівної системи. Досвід та перспективи розвитку міст України. 2014. № 27. С. 161-169.

38. Ковальська Г. Л. Прийоми модернізації мережі закладів освіти в забудові найкрупніших міст. Досвід та перспективи розвитку міст України. 2011. № 20. С. 243-249.

39. Ковальська Г. Л. Проблеми кооперування та блокування навчальних закладів у сучасних умовах: перспективні напрямки проектування житлових та громадських будівель. Архітектурно-будівельна галузь в умовах економічної кризи. 2009. № 3. С. 38-44.

40. Змеул С. Г. Новые типы зданий детских дошкольных учреждений: автореф. дис. ... д-ра арх.: 18.00.02 / Моск. архит. ин-т. Москва, 1988. 24 с.

41. Чехова Л.Н. Формирование сети и типов зданий детских дошкольных учреждений в сельской местности (на примере Московской области): дис. ... канд. арх.: 18.00.02 / Моск. архит. ин-т. Москва, 1993. 204 с.

42. Кадуріна А. О. Архітектурно-художні аспекти формування дитячих дошкільних закладів (на прикладі Одеси): автореф. дис. ... канд. арх.: 18.00.01 / Нац. акад. образотв. мистецтва і архітектури. Київ, 2005. 20 с.

43. Юрчишин О. М. Об'єкти дитячого дошкільного та позашкільного виховання надмалої місткості в житловому середовщі: автореф. дис. ... канд. арх.: 18.00.02 / Національний університет «Львівська політехніка». Львів, 2009. 24 с. 